\begin{tabular}{|c|c|c|}
\hline & $\begin{array}{l}\text { International Journal of Environment, Agriculture and Biotechnology } \\
\qquad \text { Vol-6, Issue-1; Jan-Feb, } 2021\end{array}$ & (2) \\
\hline IJEAB & $\begin{array}{c}\text { Journal Home Page Available: } \underline{\text { https://ijeab.com/ }} \\
\text { Journal DOI: } 10.22161 / \text { ijeab }\end{array}$ & \\
\hline
\end{tabular}

\title{
Seaweed Cultivationn Business Development Strategy (Gracillaria sp) Through Spores Culture in Takalar Regency
}

\author{
Evi Angriani ${ }^{1}$, Sutinah Made ${ }^{2}$, Hamzah Tahang ${ }^{2}$
}

\author{
${ }^{1}$ Student of Master Degree Fisheries Science, Faculty of Marine and Fisheries Science, Hasanuddin University, Perintis Kemerdekaan St \\ Km 10, Makassar 90245, Indonesia \\ ${ }^{2}$ Department of Fisheries Science, Faculty of Marine and Fisheries Science, Hasanuddin University, Perintis Kemerdekaan St Km 10, \\ Makassar 90245, Indonesia
}

Received: 15 Nov 2020; Received in revised form: 09 Jan 2021; Accepted: 22 Jan 2021; Available online: 01 Feb 2021 (C2021 The Author(s). Published by Infogain Publication. This is an open access article under the CC BY license (https://creativecommons.org/licenses/by/4.0/).

\begin{abstract}
This study aims to calculate income and determine alternative strategies for seaweed cultivation business development (Gracillaria sp) through spores culture in Takalar Regency. Using revenue, IE, SWOT, and QSPM formula analysis methods. The results showed that farmers in Sanrobone subdistrict earned a higher income of Rp.3,609,100 compared to Mappakasunggu District which earned revenues of Rp.2,234,500. While the total score of values in the internal matrix is 2.92 and the external matrix is 1.31. The combination of the two values indicates the position of the business lies in cell VIII or growth strategy. The right strategy is to use quality seeds to increase export value, optimize the region as a productive area, and provide stock of spore seeds for export needs. These three strategies can be implemented simultaneously, because they support each other.
\end{abstract}

Keywords—seaweed, gracillaria sp, spores culture, IE, SWOT, QSPM.

\section{INTRODUCTION}

Gracillaria sp seaweed utilization is so widely characterized by the growing market demand. However, the increasing need for seaweed production is not offset by a promising increase in production. During the period 2015 to 2018, there was a significant decrease in production, namely from 103.995 million tons in 2015 to 74.131 million tons in 2018 (DKP Takalar, 2019). The decrease in production in the seaweed cultivation business Gracillaria sp will affect the amount of income received by seaweed farmers.

Cultivation of Gracilaria sp through spores culture is one of the best solutions to increase the amount of production in seaweed cultivation efforts that are beneficial for seaweed growers for industrial-scale development that requires large amounts of seeds, timely, flexibility of storage time and does not depend on natural conditions. The use of spores as a source of seeds has been successfully carried out in several countries, including Japan and Korea. In addition, several studies on sporingspores have been conducted, among others, factors that influence the sporulation of Gracillaria cornea (Alberto and Robledo, 1999) and the paste of Gracilariagigas spores in several subsrats (Lideman et al., 2016).

Currently, some seaweed farmers in Takalar district use seeds from spores culture, where the growth of seaweed spores culture cultivated is very significant because the differences that local seeds produce with seeds from cultures are very different. Local seaweed has a certain season and location, compared to seaweed spores culture cultivators are very tolerant of the seasons and locations.

Based on the description described above about seaweed cultivation business that is still low quality but high market demand and the potential of water in Takalar 
Regency of South Sulawesi Province is very large, the need to be multiplication of seedlings through spores culture to improve the results of seaweed cultivation efforts. Therefore, a strategy is needed for the development of gracilaria sp cultivation business so that seaweed production in the coming year is better, so that the income of seaweed farmers will increase.

\section{RESEARCH METHODS}

The research was conducted in Takalar Regency in two sub-districts. This research was conducted from September 2019 to March 2020. Primary data is data obtained directly from sources studied through interviews and surrvey (questionnaires) with seaweed farmers. The method of selecting respondents at the research site was carried out purposively with the consideration that in the sub-district is one of the production centers gracilaria $\mathrm{sp}$ that uses spore seeds. This study used three analyses namely revenue analysis, IE analysis, SWOT analysis, and QSPM analysis.

Tabel 1. Average Income in seaweed cultivation business Gracillaria sp in Takalar Regency

\begin{tabular}{c|l|r|r}
\hline \multirow{2}{*}{ No } & Description & \multicolumn{2}{|c}{ District } \\
\cline { 3 - 4 } & & Sanrobone & \multicolumn{1}{c}{ Mappakasunggu } \\
\hline 1 & Acceptance & 8.370 .000 & 6.540 .000 \\
\hline 2 & Total Cost & 4.760 .900 & 4.305 .500 \\
\hline \multicolumn{2}{|c|}{ Average Income (RP) } & $\mathbf{3 . 6 0 9 . 1 0 0}$ & $\mathbf{2 . 2 3 4 . 5 0 0}$ \\
\hline
\end{tabular}

\section{RESULTS AND DISCUSSION}

\subsection{Seaweed Grower Income}

Income is the result of receipts reduced by the total costs incurred during the seaweed cultivation process Gracilaria sp. The purpose of the calculation of income is to find out how much net income from seaweed cultivation business through spores culture. The higher the income received by seaweed farmers, the higher the amount of goods consumed both in terms of quality and quantity of goods to be consumed.

One of the things to note in running a business is the cost of production. Where the cost of production is the total cost of all costs used from production preparation to marketing. In table 1 , the total income obtained by seaweed farmers in Takalar Regency is presented as follows :

Source : Primary data after processing, 2020

From the table above, it is seen that the income received by seaweed farmers Gracilariasp in Sanrobone District amounted to Rp. 3.609.100 per production. While the revenue received by seaweed farmers in Mappakasunggu District amounted to Rp. 2,234,500 per production. Average income of seaweed cultivation Gracilariasp that uses spore seeds when compared to seaweed cultivation Gracilariasp in the pond has a relatively small income difference or the average amount of income received is almost the same. This is in accordance with the research of Riskiyani (2019), where the average income received by seaweed farmers in Takalar Regency amounted to Rp. 1,229,452.

\subsection{Seaweed Cultivation Business Development Strategy}

\subsubsection{Identification of Internal and External Factors}

According to Zain (2012) in planning the strategy should analyze the external environment (opportunities and threats) to know the various possible opportunities and threats. The problem of the strategy to be monitored must be determined because this problem may affect future efforts. After completing the analysis of external strategic factors, it should also analyze the internal strategy factors (strengths and weaknesses). The internal and external factors of seaweed cultivation business Gracillaria sp in Takalar regency as follows : 
Table 2. Internal and external factors

\begin{tabular}{|c|c|}
\hline Internal Factors & External Factors \\
\hline STRENGHTS & OPPORTUNITIES \\
\hline Seaweed cultivation area & Seaweed cultivation investors \\
\hline Seaweed cultivation business experience & Market demand is still high \\
\hline Quality seeds & Increase the value of exports \\
\hline Effective use of capital & Government assistance \\
\hline WEAKNESSES & THREATS \\
\hline Land use is not optimal & Level of competition with similar businesses \\
\hline The number of cultivators is still low & Fluctuating prices \\
\hline Limitations of spore culture seeds & The influence of the seasons \\
\hline Presence of pests and diseases & \\
\hline
\end{tabular}

Source : Primary data after processing, 2020

\subsubsection{Business position based on IE matrix}

\subsubsection{IFE Matrix}

Identification of internal factors in the form of strengths and weaknesses affect the development of seaweed cultivation business Gracillaria sp in Takalar Regency. The result of identification of strengths and weaknesses as an internal strategy factor, is then given weight and rating for each factor so that the total score is obtained. The results of internal factor analysis obtained the number of selisishnya as follows :

Table 2. IFE Matrix

\begin{tabular}{llll}
\hline \multicolumn{1}{c}{ Internal Factors Strategy } & Weights & Rating & Valeur \\
\hline Strengths & 0,19 & 4,00 & 0,76 \\
\hline Seaweed cultivation area & 0,13 & 2,67 & 0,34 \\
Seaweed cultivation business experience & 0,19 & 4,00 & 0,76 \\
Quality seeds & 0,11 & 2,33 & 0,26 \\
Effective use of capital & $\mathbf{0 , 6 2}$ & $\mathbf{2 , 1 2}$ \\
\hline Amount & & 1,67 & 0,13 \\
\hline Weaknesses & 0,08 & 0,19 \\
\hline Land use is not optimal & 0,10 & 2,00 & 0,34 \\
The number of cultivators is still low & 0,13 & 2,67 & 0,13 \\
Limitations of spore culture seeds & 0,08 & 1,67 & $\mathbf{0 , 7 9}$ \\
Presence of pests and diseases & $\mathbf{0 , 3 8}$ & $\mathbf{2 , 9 2}$ \\
\hline Amount & $\mathbf{1 , 0 0}$ & & \\
\hline Total
\end{tabular}

Source : Primary data after processing, 2020

Based on the results of the analysis from the table above obtained the number of strength scores with a value of 2.12 and the number of weakness scores with a value of 0.79 in seaweed cultivation business Gracillaria sp. So that obtained a total score of 2.92 which shows the internal factor is above the average value of 2.5 which indicates the internal position of seaweed cultivation business Gracillaria sp strong enough that seaweed cultivation business has the ability above average in utilizing strengths and anticipating internal weaknesses. 


\subsubsection{EFE Matrix}

Identification of external factors is carried out to determine the opportunities and threats faced by seaweed growers Gracillaria sp. Identification results are collected to analyze external factors. Furthermore, it is given weight and rating for each factor so that the total score is obtained. The results of internal factor analysis obtained the number of selisishnya as follows:

Table 3. EFE Matrix

\begin{tabular}{llll}
\hline \multicolumn{1}{c}{ External Strategy Factors } & Weights & Rating & Valeur \\
\hline Opportunities & & 3,00 & 0,42 \\
\hline Seaweed cultivation investors & 0,14 & 4,00 & 0,75 \\
Market demand is still high & 0,19 & 4,00 & 0,75 \\
Increase the value of exports & 0,19 & 2,67 & 0,33 \\
Government assistance & 0,13 & $\mathbf{2 , 2 6}$ \\
\hline Amount & $\mathbf{0 , 6 4}$ & 0,42 \\
\hline Threats & & 4 & 0,42 \\
\hline Level of competition with similar businesses & 0,14 & 4 & 0,13 \\
Fluctuating prices & 0,14 & 3 & $\mathbf{0 , 9 7}$ \\
The influence of the seasons & 0,08 & $\mathbf{1 , 3 1}$ \\
\hline Amount & $\mathbf{0 , 3 6}$ & $\mathbf{1 , 0 0}$ & \\
\hline Total & & & \\
\hline
\end{tabular}

Source : Primary data after processing, 2020

Based on the table above obtained the number of opportunities gracillaria sp seaweed cultivation business with a value of 2.26 and the number of scores against the threat of seaweed cultivation with a value of 0.97 . So the total score obtained from the analysis is 1.31 . This value indicates that the company's external position is not strong, namely the seaweed cultivation business Gracillaria sp does not have the ability above average in utilizing opportunities and anticipating external threats.
The results of the internal matrix evaluation are further combined with the results of the evaluation of the external matrix that produces the IE matrix, so that the business position can be mapped to make it easier to formulate alternative business development strategies. The strategic positioning of the IE matrix is based on the results of the total IFE values weighted on the $\mathrm{x}$-axis and the total EFE values on the y-axis (Setyaningsih, 2012). The results of IE matrix analysis on seaweed cultivation business in Takalar Regency are as follows :

\subsubsection{IE Matrix}

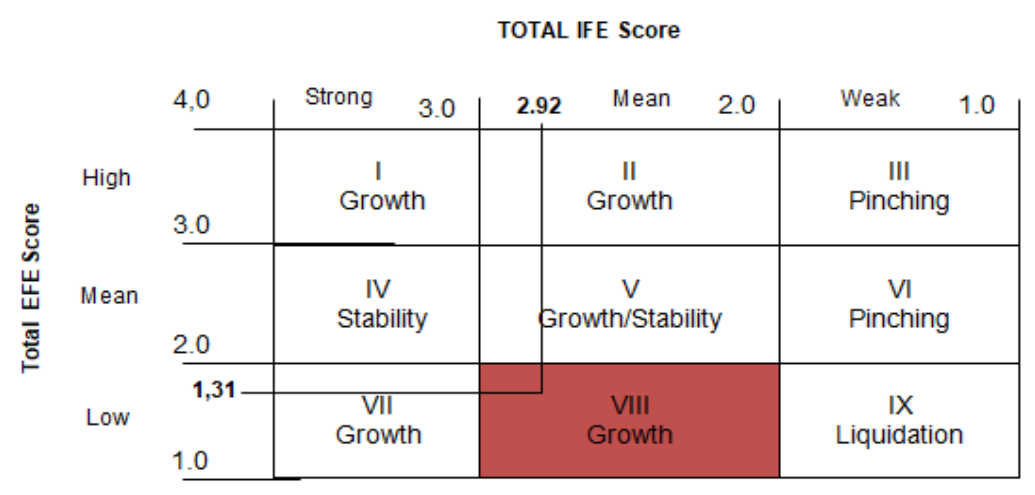

Fig.1: IE Matrix

\subsubsection{SWOT Analysis}

SWOT can describe how the opportunities and threats from the external environment of gracillaria sp seaweed cultivation business are anticipated with its strengths and weaknesses. This matrix can produce four sets of strategies, each of which is as follows: 
Table 4. SWOT analysis matrix

\begin{tabular}{|c|c|c|}
\hline INTERNAL & $\begin{array}{l}\text { Strengths } \\
\text { a. Seaweed cultivation area } \\
\text { b. Long business experience } \\
\text { c. Quality seeds } \\
\text { d. Effective use of capital }\end{array}$ & $\begin{array}{l}\text { Weaknesses } \\
\text { a. Land use is not optimal } \\
\text { b. The number of Gracilariasp } \\
\text { cultivators is still low } \\
\text { c. Limitations of spore culture seeds } \\
\text { d. Presence of pests and diseases }\end{array}$ \\
\hline $\begin{array}{l}\text { Opportunities } \\
\text { a. Seaweed cultivation investors } \\
\text { b. Market demand is still high } \\
\text { c. Increase the value of exports } \\
\text { d. Government assistance }\end{array}$ & \begin{tabular}{|l} 
Strategy $\mathbf{S}>\mathbf{O}$ \\
1. \\
Designing the development of \\
gracillariasp cultivation area (S1,O1) \\
2. Optimizing your experience to \\
facilitate seaweed marketing and \\
production (S2,O2) \\
3. Use of quality seeds to increase \\
export value (S3,O3) \\
4. Improving business efficiency \\
through optimization of government \\
assistance utilization (S4,O4)
\end{tabular} & 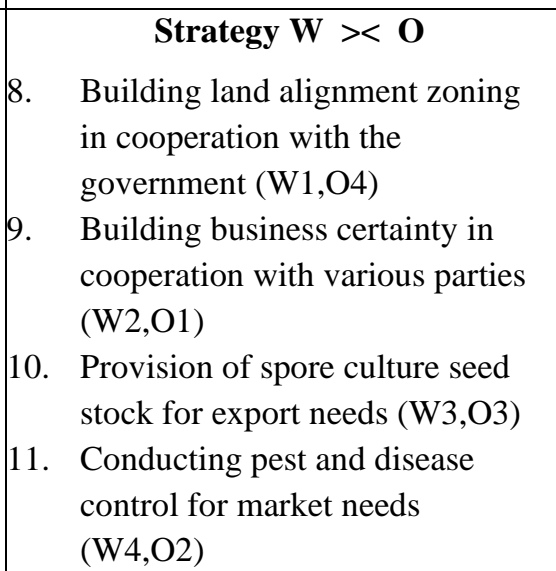 \\
\hline $\begin{array}{l}\text { Ancaman ( Threats ) } \\
\text { a. Level of competition with } \\
\text { similar businesses } \\
\text { b. Fluctuating prices } \\
\text { c. The influence of the seasons }\end{array}$ & $\begin{array}{l}\text { Strategy } \mathbf{S}>\mathbf{T} \\
\text { 5. Optimizing the region as a productive } \\
\text { area(S1,S4,T1) } \\
\text { 6. Diversifying products so that prices } \\
\text { can be controlled }(\mathrm{S} 2, \mathrm{~T} 2) \\
\text { 7. Maintaining the quality of the use of } \\
\text { spore culture seeds to minimize the } \\
\text { impact of the changing seasons } \\
(\mathrm{S} 3, \mathrm{~T} 3)\end{array}$ & 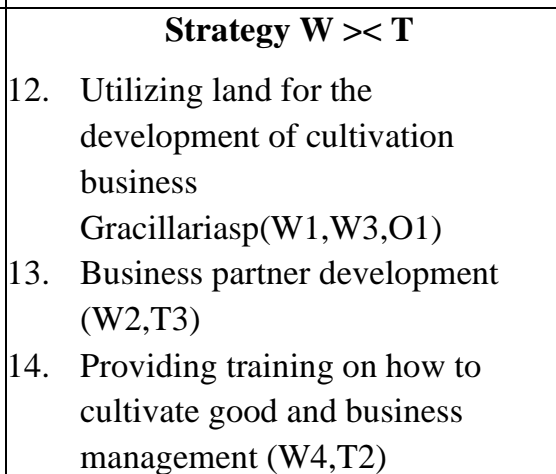 \\
\hline
\end{tabular}

Source : Primary data after processing, 2020

\subsubsection{QSPM Analysis}

Quantitative Strategic Planning Matrix (QSPM) is a tool that allows strategists to evaluate alternative strategies objectively based on important external and internal success factors previously identified. The matrix objectively demonstrates the best alternative strategies.
QSPM uses inputs from SWOT matrix analysis to obtain the information needed to build a QSPM matrix. The MATRIX QSPM (Quantitave Strategies Planning Matrix) seaweed cultivation business Gracillaria $\mathrm{sp}$ in Takalar Regency as follows :

Table 5. QSPM analysis matrix

\begin{tabular}{l|c|c|c}
\hline \multicolumn{1}{c|}{ Alternative Strategies } & Linkages & Weights & Ranking \\
\hline Strategy S-O & S1,O1 & 0,85 & \multicolumn{2}{c}{ IV } \\
\hline Designing the development of gracillariasp cultivation area & S2,O 2 & 0,64 & VII \\
\hline $\begin{array}{l}\text { Optimizing your experience to facilitate seaweed marketing } \\
\text { and production }\end{array}$ & S3,O3 & 1,14 & I \\
\hline $\begin{array}{l}\text { Use of quality seeds to increase export value } \\
\begin{array}{l}\text { Improving business efficiency through optimization of } \\
\text { government assistance utilization }\end{array}\end{array}$ & S4,O4 & 0,37 & XI \\
\hline
\end{tabular}




\begin{tabular}{|c|c|c|c|}
\hline \multicolumn{4}{|l|}{ Strategy S-T } \\
\hline Optimizing the region as a productive area & $\mathrm{S} 1, \mathrm{~S} 4, \mathrm{~T} 1$ & 1,02 & II \\
\hline Diversifying products so that prices can be controlled & $\mathrm{S} 2, \mathrm{~T} 2$ & 0,55 & VIII \\
\hline $\begin{array}{l}\text { Maintaining the quality of the use of spore culture seeds to } \\
\text { minimize the impact of the changing seasons }\end{array}$ & $\mathrm{S} 3, \mathrm{~T} 3$ & 0,54 & IX \\
\hline \multicolumn{4}{|l|}{ Strategy W-O } \\
\hline $\begin{array}{l}\text { Building land alignment zoning in cooperation with the } \\
\text { government }\end{array}$ & $\mathrm{W} 1, \mathrm{O} 4$ & 0,34 & XII \\
\hline Building business certainty in cooperation with various parties & $\mathrm{W} 2, \mathrm{O} 1$ & 0,38 & $\mathbf{X}$ \\
\hline Provision of spore culture seed stock for export needs & $\mathrm{W} 3, \mathrm{O} 3$ & 0,96 & III \\
\hline Conducting pest and disease control for market needs & $\mathrm{W} 4, \mathrm{O} 2$ & 0,81 & $\mathbf{V}$ \\
\hline \multicolumn{4}{|l|}{ Strategy W-T } \\
\hline $\begin{array}{l}\text { Utilizing land for the development of cultivation business } \\
\text { Gracillariasp }\end{array}$ & $\mathrm{W} 1, \mathrm{~W} 3, \mathrm{O} 1$ & 0,70 & VI \\
\hline Business partner development & $\mathrm{W} 2, \mathrm{~T} 3$ & 0,18 & XIII \\
\hline $\begin{array}{l}\text { Providing training on how to cultivate good and business } \\
\text { management }\end{array}$ & $\mathrm{W} 4, \mathrm{~T} 2$ & 0,64 & VII \\
\hline
\end{tabular}

Source : Primary data after processing, 2020

Based on the results of the analysis from the table above shows that the most appropriate strategies for business development are the improvement of quality seeds to increase the value of exports (score 1.20), provision of spore culture seed stocks for export needs (score 1.05), and optimize the region as a productive area (0.95). These three strategies can be implemented simultaneously because they support each other.

\section{CONCLUSION}

The results showed that farmers in Sanrobone subdistrict earned a higher income of Rp.3,609,100 compared to Mappakasunggu District which earned revenues of Rp.2,234,500. While the total score of values in the internal matrix is 2.92 and the external matrix is 1.31. The combination of the two values indicates the position of the business lies in cell VIII or growth strategy. The right strategy is to use quality seeds to increase export value, optimize the region as a productive area, and provide stock of spore seeds for export needs. These three strategies can be implemented simultaneously, because they support each other.

\section{REFERENCES}

[1] Amiruddin, (2017). Perumusan Strategi Menggunakan Analisis SWOT dan QSPM Dalam Menentukan Arah Pengembangan Bisnis. Program Studi Magister Manajemen Sekolah Pascasarjana Universitas Hasanuddin, Makassar
[2] BPS. (2019). Kabupaten Takalar Provinsi Sulawesi Selatan : Badan Pusat Statistik Provinsi Sulawesi Selatan.

[3] Bangun, W. (2010). Teori Ekonomi Mikro. Refika Aditama, Bandung.

[4] Bhakti, Fachri Kurnia, Sutinah Made, Mardiana E. Fachry, (2014). Kondisi Pemasaran Rumput Laut Gracillaria sp Melalui Pendekatan SCP di Kabupaten Luwu. Sekolah Pascasarjana Universitas Hasanuddin Makassar. J.Sains \& Teknologi, Desember 2014, Vol.14 No.3 : 291-300 ISSN 1411-4674.

[5] Diana, Farah, (2014). Analisis Keragaan Rumput Laut (Gracillaria gigas) Pada Sistem Budidaya Laut dan Tambak di Nusa Tenggara Barat.Sekolah Pascasarjana Institut Pertanian Bogor.

[6] KKP, (2016). Laut Indonesia : Potensi Besar Perikanan Tangkap : Kementerian Kelautan dan Perikanan

[7] Lideman , dkk , (2016). Petunjuk Teknis Produksi Bibit Gracillaria Laut (Gracillaria sp) Melalui Kultur Spora Pada Tali di Kabupaten Takalar. Balai Perikanan Budidaya Air Payau Takalar. Juknis Kultur Spora Gracillaria sp.

[8] Nahdyah, NS., Aisjah, F \&Ilham, J, (2014). Keragaman Jenis Kapal Perikanan di Kabupaten Takalar. Jurnal IPTEKS PSP Vol.1, No.1 Makassar.

[9] Putri, Dede, Wuryaningsih Dwi Sayekti, Novi Rosanti,(2014). Analisis Pendapatan dan Strategi Pengembangan Budidaya Rumput Laut di Pulau Pahawang Kecamatan Punduh Pidada Kabupaten Pasarawang. Jurusan Agribisnis Universitas Lampung. JIIA, Volume 2, No, 1, Januari 2014.

[10] Qalsum, Ummy, Andriyono Kilat Adhi, \& Anna Fariyanti, (2018). Pemasaran dan Nilai Tambah Rumput Laut di Kabupaten Takalar, Provinsi Sulawesi Selatan. Jurnal Ilmiah Manajemen Vol. 8 No. 3. 
[11] Rangkuti., Freddy, (2015). Analisis SWOT Teknik Membedah Kasus Bisnis. PT.Gramedia Pusaka Utama, Jakarta.

[12] Riskiyani., (2019). Analisis Ouput-Input Usaha Budidaya Rumput Laut. Jurusan Agribisnis Sekolah Pascasarjana Universitas Hasanuddin, Makassar.

[13] Umar., Husein., (2010). Desain Penelitian Manajemen Strategik. PT. Raja Grafindo Persada, Jakarta.

[14] Valderrama., DJ, Cai, N, Hishamunda \&Ridler, (2013). Social and Economic Dimensions of Carrageenan Seaweed Farming: Fisheries and Aquaculture Technical Paper. No.580. FAO. Rome.

[15] Yudiati., E, E, S, Susilo\&C., A., Suryono, (2004). Teknik Setting Spora Gracillaria gigas Sebagai Penyedia Benih Unggul Dalam Budidaya Rumput Laut. Ilmu Kelautan. Vol. 8, No, 1, 37-40. 